\title{
PEMANFAATAN HASIL HUTAN BUKAN KAYU OLEH MASYARAKAT \\ GALIK SEKAM DESA KASRO MEGO KECAMATAN BEDUAI KABUPATEN SANGGAU
}

\author{
Kamaludin \\ Fakultas Pertanian Universitas Kapuas Sintang \\ e-mail: kamaludinkamal27@yahoo.co.id
}

\begin{abstract}
Abstrak: Penelitian ini bertujuan untuk mengetahui pemanfaatan hasil hutan bukan kayu oleh masyarakat galik sekam desa kasro mego kecamatan beduai kabupaten sanggau. Metode yang digunakan dalam penelitian ini adalah metode survey dengan teknik pengumpulan data melalui wawancara, pengamatan langsung (observasi), dokumentasi, catatan lapangan dan studi literatur. Populasi dalam penelitian ini adalah masyarakat Desa Kasro Mego Kecamatan Beduai yang memanfaatkan HHBK. Teknik pengambilan sampel akan dilakukan secara sengaja (purposive sample).

Dari hasil penelitian ditemukan 33 Jenis tumbuhan termasuk Kelompok HHBK dan dimanfaatkan oleh masyarakat Desa Kasro Mego Kecamatan Beduai. Ada jenis-jenis tumbuhan mempunyai kegunaan lebih dari satu bila dilihat dari kategori kelompok HHBK. Potensi HHBK yang masih ada di Hutan Galik Sekam dapat dilihat dari pemanfaatan oleh masyarakat setempat. Pemanfaatan HHBK oleh masyarakat Desa Kasro Mego memiliki peranan penting terutama untuk keperluan dan kebutuhan sendiri, serta beberapa untuk meningkatkan penghasilan atau pendapatan masyarakat itu sendiri.
\end{abstract}

Kata kunci : hasil hutan bukan kayu dan masyarakat Galik Sekam

\section{PENDAHULUAN}

Hutan di Indonesia memiliki keanekaragam hayati yang sangat berlimpah. Sumber daya hutan mempunyai fungsi yang dapat memberikan manfaat ekonomi, lingkungan dan sosial bagi umat manusia. Sumber daya hutan juga bersifat multiguna dan memuat multi kepentingan serta pemanfaatannya diarahkan untuk mewujudkan sebesar-besarnya kemakmuran rakyat. Manfaat tersebut bukan hanya berasal dari hasil hutan kayu, melainkan juga manfaat hasil hutan bukan kayu (HHBK) dan jasa lingkungan (pemanfaatan aliran air, pemanfaatan air, wisata alam dan perlindungan keanekaragaman 
Pemanfaatan Hasil Hutan Bukan Kayu Oleh Masyarakat Galik Sekam

Desa Kasro Mego Kecamatan Beduai Kabupaten Sanggau

hayati), namun hingga saat ini

potensi HHBK dan jasa lingkungan

belum dapat dimanfaatkan secara optimal.

Hutan dan masyarakat di sekitarnya merupakan suatu bagian yang tidak dapat dipisahkan. Secara turun-temurun kehidupan masyarakat di sekitar hutan sangat bergantung pada hutan. Selain sebagai penyedia bahan pangan, hutan juga dapat memberi penghasilan tambahan yaitu dari HHBK misalnya binatang buruan, damar, gaharu, rotan, madu dan lain-lain. Namun, potensi HHBK masih belum banyak diketahui atau dimanfaatkan oleh masyarakat secara bijaksana, karena saat ini kegiatan produksi hutan lebih banyak diketahui oleh masyarakat pada hasil kayu bulat untuk ekspor dan industri kayu.

Pemanfaatan HHBK juga dilakukan oleh masyarakat Desa Kasro Mego Kecamatan Beduai Kabupaten Sanggau. Wilayah tersebut terdapat suatu kawasan berhutan yang berperan penting dalam menopang kehidupan masyarakat sehari-hari dan mempunyai nilai sosial dan budaya bagi masyarakat setempat. Di hutan tersebut masih terdapat keanekaragaman tumbuhan..

\section{METODE PENELITIAN}

Metode yang digunakan dalam penelitian ini adalah metode survey dengan teknik pengumpulan data melalui wawancara, pengamatan langsung (observasi), dokumentasi, catatan lapangan dan studi literatur. Populasi dalam penelitian ini adalah masyarakat Desa Kasro Mego Kecamatan Beduai yang memanfaatkan HHBK. Teknik pengambilan sampel akan dilakukan secara sengaja (purposive sample). Jumlah sampel sebanyak 20-25\% atau lebih dari populasi, karena menurut Arikunto (2010: 112), jika subjeknya besar atau lebih dari 100 orang dapat diambil 10-15\% atau 20$25 \%$ atau lebih.

$$
\text { Peralatan yang akan di }
$$
gunakan dalam penelitian ini adalah meliputi peta lokasi, untuk mengetahui tempat penelitian, Kamera digunakan untuk mendokumentasikan semua kegiatan penelitian, alat perekam suara, untuk merekam proses wawancara, Alat 
Pemanfaatan Hasil Hutan Bukan Kayu Oleh Masyarakat Galik Sekam

Desa Kasro Mego Kecamatan Beduai Kabupaten Sanggau

tulis menulis digunakan untuk
mencatat semua data sekunder
maupun data primer hasil
pengamatan di lapangan. Alat tulis
menulis yang digunakan antara lain
kertas, pensil, ballpoint, Buku
identifikasi HHBK sebagai referensi
atau literatur dalam mengidentifikasi
jenis HHBK yang ditemukan pada
saat penelitian.Tally sheet untuk
mencatat jenis HHBK. Bahan yang
digunakan dalam penelitian adalah
semua jenis HHBK yang
dimanfaatkan oleh masyarakat Desa
Kasro Mego Kecamatan Beduai
Kabupaten Sanggau yang berasal
dari Hutan Sekam Galik.

HASIL DAN PEMBAHASAN

Hasil

Hasil penelitian yang
dilakukan melalui pengamatan
(observasi) di Hutan Sekam Galik
Desa Kasro Mego Kecamatan
Beduai, ditemukan jenis tumbuhan
yang termasuk dalam kelompok
Hasil Hutan Bukan Kayu (HHBK)
yang dimanfaatkan oleh masyarakat.
Kelompok jenis tumbuhan yang
ditemukan ada 5 yang terdiri atas
kelompok resin, kelompok minyak
lemak, pati dan buah-buahan,
kelompok tannin, bahan pewarna dan
getah, kelompok tumbuhan obat dan
tanaman hias, kelompok palma dan
bambu.. Lebih jelasnya untuk jenis
kelompok tumbuhan yang
ditemukan di Desa Kasro Mego
dapat dilihat pada tabel berikut ini


Pemanfaatan Hasil Hutan Bukan Kayu Oleh Masyarakat Galik Sekam

Desa Kasro Mego Kecamatan Beduai Kabupaten Sanggau

Tabel 1. Kelompok HHBK yang ditemukan di Desa Kasro Mego

\begin{tabular}{|c|c|c|c|}
\hline $\mathrm{N}$ & Kelompok HHBK & Nama Lokal & Nama latin \\
\hline 1. & $\begin{array}{l}\text { Hasil Tumbuhan dan } \\
\text { Tanaman } \\
\text { Resin }\end{array}$ & Damar Gaharu & $\begin{array}{l}\text { Famili Dipterocarpaceae } \\
\text { Gyrinops versteegii }\end{array}$ \\
\hline & $\begin{array}{l}\text { Minyak Lemak, Pati } \\
\text { dan Buah-buahan }\end{array}$ & $\begin{array}{l}\text { Tengkabak Laye } \\
\text { Tengkabak Ramei } \\
\text { Asam Konis } \\
\text { Berinang } \\
\text { Budak } \\
\text { Buntat } \\
\text { Diat } \\
\text { Entowok } \\
\text { Kelampai } \\
\text { Kuronyek } \\
\text { Maca } \\
\text { Mayang Aren } \\
\text { Tampoi } \\
\end{array}$ & $\begin{array}{l}\text { Shorea mecistopteryx Ridl. } \\
\text { Shorea leprosula } \\
\text { Garcinia xanthocymus } \\
\text { Averrhoa } \\
\text { Artocarpus champeden } \\
\text { Cocos nucifera } \\
\text { Durio zibethinus } \\
\text { Artocarpus anisphyllus } \\
\text { Dacryodes rostata } \\
\text { Dialium indum } \\
\text { Mangifera Foetida } \\
\text { Arenga pinnata } \\
\text { Baccaurea macrocarpa }\end{array}$ \\
\hline & $\begin{array}{l}\text { Tannin, bahan } \\
\text { pewarna dan getah }\end{array}$ & Uwi jeronang & Daemonorops draco \\
\hline & Tumbuhan obat & $\begin{array}{l}\text { Engkudu } \\
\text { Pina } \\
\text { Damar } \\
\text { Akar Entuyut } \\
\text { Akar Kuning } \\
\text { Ketepeng } \\
\text { Sengkubak }\end{array}$ & $\begin{array}{l}\text { Morinda citrifolia } \mathrm{L} . \\
\text { Areca catechu } \\
\text { Famili Dipterocarpaceae } \\
\text { Nepenthes sp } \\
\text { Arcangelisia Flava Merr. } \\
\text { Casia alata L. } \\
\text { Pycnarrhena cauliflora }\end{array}$ \\
\hline 2. & \multicolumn{2}{|c|}{$\begin{array}{l}\text { Palem - paleman dan Bambu } \\
\text { Buntat } \\
\text { Bambu betung } \\
\text { Bambu munti } \\
\text { Bambu tengayang } \\
\text { Mayang } \\
\text { Uwi jeronang } \\
\text { Uwi marao } \\
\text { Uwi sogah }\end{array}$} & $\begin{array}{l}\text { Cocos nucifera } \\
\text { Dendrocalamus asper } \\
\text { Thyrsostachys siamensis } \\
\text { Gigantochloa apus Kurz. } \\
\text { Arenga pinnata } \\
\text { Daemonorops draco } \\
\text { Calamus manan Mig. } \\
\text { Calamus caesius Blume. }\end{array}$ \\
\hline \multirow[t]{3}{*}{3.} & \multirow[t]{3}{*}{ Kelompok Lain } & Bemban & Donax canniformis \\
\hline & & Kepuak & Artocarpus sp. \\
\hline & & Uwi jeronang & Daemonorops draco \\
\hline
\end{tabular}


Pemanfaatan Hasil Hutan Bukan Kayu Oleh Masyarakat Galik Sekam

Desa Kasro Mego Kecamatan Beduai Kabupaten Sanggau

Tabel 2. Daftar Tumbuhan dalam kelompok HHBK dan pemanfaatannya

\begin{tabular}{|c|c|c|c|c|c|}
\hline No & $\begin{array}{r}\text { Nama } \\
\text { daerah }\end{array}$ & Nama Latin & $\begin{array}{c}\text { Bagian Yang } \\
\text { Dimanfaatkan } \\
\end{array}$ & Manfaat & Produk \\
\hline 1 & 2 & 3 & 4 & 5 & 6 \\
\hline 1 & $\begin{array}{l}\text { Akar } \\
\text { Entuyut }\end{array}$ & Nephenthes sp. & $\begin{array}{l}\text { Batang dan } \\
\text { Kantong }\end{array}$ & $\begin{array}{l}\text { Penawar bisa } \\
\text { Ular dan Obat } \\
\text { telinga } \\
\text { bernanah }\end{array}$ & $\begin{array}{l}\text { Obat } \\
\text { tradisional }\end{array}$ \\
\hline 2 & $\begin{array}{l}\text { Akar } \\
\text { Kuning }\end{array}$ & $\begin{array}{l}\text { Arcangelisia } \\
\text { flava Merr. }\end{array}$ & $\begin{array}{l}\text { Batang, Akar dan } \\
\text { Daun Muda }\end{array}$ & $\begin{array}{l}\text { Obat demam } \\
\text { dan sakit } \\
\text { kuning }\end{array}$ & $\begin{array}{l}\text { Obat } \\
\text { tradisional }\end{array}$ \\
\hline 3 & Asam Konis & $\begin{array}{l}\text { Garcinia } \\
\text { xanthocymus }\end{array}$ & Buah & Bumbu masak & Asam Konis \\
\hline 6 & $\begin{array}{l}\text { Bambu } \\
\text { Betung }\end{array}$ & $\begin{array}{l}\text { Dendrocalamus } \\
\text { asper }\end{array}$ & $\begin{array}{l}\text { Batang dan } \\
\text { rebung }\end{array}$ & $\begin{array}{l}\text { Bahan } \\
\text { membuat } \\
\text { mebel, rakit, } \\
\text { meriam } \\
\text { bambu dan } \\
\text { makanan }\end{array}$ & $\begin{array}{l}\text { Mebel, rakit, } \\
\text { meriam } \\
\text { bambu dan } \\
\text { rebung }\end{array}$ \\
\hline 7 & $\begin{array}{l}\text { Bambu } \\
\text { Munti }\end{array}$ & $\begin{array}{l}\text { Thyrsostachys } \\
\text { siamensis }\end{array}$ & Rebung & Makanan & Rebung \\
\hline 8 & $\begin{array}{l}\text { Bambu } \\
\text { Tengayang }\end{array}$ & $\begin{array}{l}\text { Gigantochloa } \\
\text { apus Kurz. }\end{array}$ & Batang & Mebel & Bahan baku \\
\hline 9 & Bemban & \begin{tabular}{|l|} 
Donax \\
canniformis
\end{tabular} & Batang & $\begin{array}{l}\text { Kerajinan } \\
\text { tangan }\end{array}$ & $\begin{array}{l}\text { Bahan } \\
\text { anyaman }\end{array}$ \\
\hline 10 & Berinang & $\begin{array}{l}\text { Averrhoa } \\
\text { bilimbi L. }\end{array}$ & Buah & $\begin{array}{l}\text { Makanan dan } \\
\text { penyampur } \\
\text { masakan }\end{array}$ & $\begin{array}{l}\text { Buah } \\
\text { Berinang }\end{array}$ \\
\hline 11 & Budak & $\begin{array}{l}\text { Artocarpus } \\
\text { champeden }\end{array}$ & Buah dan biji & $\begin{array}{l}\text { Dapat } \\
\text { dimakan }\end{array}$ & $\begin{array}{l}\text { Buah dan biji } \\
\text { Budak }\end{array}$ \\
\hline 12 & Buntat & Cocos nucifera & $\begin{array}{l}\text { Buah, air, umbut } \\
\text { dan lidi }\end{array}$ & $\begin{array}{l}\text { Dapat } \\
\text { dimakan, } \\
\text { minuman, } \\
\text { minyak } \\
\text { goreng dan } \\
\text { Sapu }\end{array}$ & $\begin{array}{l}\text { Buah, air } \\
\text { umbut, } \\
\text { Minyak } \\
\text { Kelapa dan } \\
\text { sapu lidi }\end{array}$ \\
\hline 13 & Buntat & Cocos nucifera & $\begin{array}{l}\text { Buah, air, umbut } \\
\text { dan lidi }\end{array}$ & $\begin{array}{l}\text { Makanan, } \\
\text { minuman, } \\
\text { minyak } \\
\text { goreng dan } \\
\text { Sapu }\end{array}$ & $\begin{array}{l}\text { Buah, air } \\
\text { umbut, } \\
\text { Minyak } \\
\text { Kelapa dan } \\
\text { sapu lidi }\end{array}$ \\
\hline
\end{tabular}


Pemanfaatan Hasil Hutan Bukan Kayu Oleh Masyarakat Galik Sekam

Desa Kasro Mego Kecamatan Beduai Kabupaten Sanggau

\begin{tabular}{|c|c|c|c|c|c|}
\hline 14 & Damar & - & semua bagian & $\begin{array}{l}\text { Wewangian } \\
\text { dan obat- } \\
\text { obatan }\end{array}$ & $\begin{array}{l}\text { Damar Dan } \\
\text { Obat } \\
\text { tradisional }\end{array}$ \\
\hline 15 & Diat & Durio zibethinus & Buah & $\begin{array}{l}\text { Dapat } \\
\text { dimakan }\end{array}$ & $\begin{array}{l}\text { Buah, } \\
\text { tempoyak } \\
\text { dan lempok } \\
\text { durian }\end{array}$ \\
\hline 16 & Engkudu & $\begin{array}{l}\text { Morinda } \\
\text { citrifolia } \mathrm{L} \text {. }\end{array}$ & Buah dan daun & $\begin{array}{l}\text { Obat tekanan } \\
\text { darah tinggi, } \\
\text { kejang, kurang } \\
\text { nafsu makan, } \\
\text { dan gangguan } \\
\text { saluran darah }\end{array}$ & $\begin{array}{l}\text { Obat } \\
\text { tradisional }\end{array}$ \\
\hline 17 & Engkudu & $\begin{array}{l}\text { Morinda } \\
\text { citrifolia } \mathrm{L} \text {. }\end{array}$ & Buah dan daun & $\begin{array}{l}\text { Obat tekanan } \\
\text { darah tinggi, } \\
\text { kejang, kurang } \\
\text { nafsu makan, } \\
\text { gangguan } \\
\text { saluran darah } \\
\end{array}$ & $\begin{array}{l}\text { Obat } \\
\text { tradisional }\end{array}$ \\
\hline 18 & Entowok & $\begin{array}{l}\text { Artocarpus } \\
\text { anisphyllus }\end{array}$ & Buah & $\begin{array}{l}\text { Dapat } \\
\text { dimakan }\end{array}$ & $\begin{array}{l}\text { Buah } \\
\text { Entowok }\end{array}$ \\
\hline 19 & Gaharu & \begin{tabular}{|l} 
Gyrinops \\
versteegii
\end{tabular} & Resin & Wewangian & Resin gaharu \\
\hline 20 & Kelampai & $\begin{array}{l}\text { Dacryodes } \\
\text { rostata }\end{array}$ & Buah & $\begin{array}{l}\text { Dapat } \\
\text { dimakan }\end{array}$ & \begin{tabular}{|l} 
Buah \\
Kelampai
\end{tabular} \\
\hline 21 & Kepuak & Artocarpus sp. & Kulit & $\begin{array}{l}\text { Pengikat dan } \\
\text { kerajinan } \\
\text { tangan }\end{array}$ & $\begin{array}{l}\text { Tali Kepuak } \\
\text { dan bahan } \\
\text { anyaman }\end{array}$ \\
\hline 22 & Ketepeng & Casia alata $\mathrm{L}$. & Daun dan akar & $\begin{array}{l}\text { obat borok, } \\
\text { eksim, gatal di } \\
\text { sekitar } \\
\text { pangkal } \\
\text { kelamin, panu } \\
\text { dan radang } \\
\text { kulit }\end{array}$ & $\begin{array}{l}\text { Obat } \\
\text { tradisional }\end{array}$ \\
\hline 23 & Kuronyek & Dialium indum & Buah & $\begin{array}{l}\text { Dapat } \\
\text { dimakan }\end{array}$ & \begin{tabular}{|l} 
Buah \\
Kuronyek
\end{tabular} \\
\hline 24 & Mayang & Arenga pinnata & Buah, air dan lidi & $\begin{array}{l}\text { Dapat } \\
\text { dimakan, } \\
\text { minuman dan } \\
\text { bahan untuk } \\
\text { Sapu }\end{array}$ & $\begin{array}{l}\text { Gula } \\
\text { Mayang, } \\
\text { umbut aren, } \\
\text { Arak atau } \\
\text { Tuak Aren, } \\
\text { Kolang- } \\
\text { kaleng, Sapu } \\
\text { Lidi } \\
\end{array}$ \\
\hline
\end{tabular}


Pemanfaatan Hasil Hutan Bukan Kayu Oleh Masyarakat Galik Sekam Desa Kasro Mego Kecamatan Beduai Kabupaten Sanggau

\begin{tabular}{|c|c|c|c|c|c|}
\hline 25 & Pina & $\begin{array}{l}\text { Areca catechu } \\
\text { L. }\end{array}$ & Buah dan batang & $\begin{array}{l}\text { Bahan untuk } \\
\text { menyirih dan } \\
\text { sebagai media } \\
\text { panjat pina }\end{array}$ & $\begin{array}{l}\text { Buah Pina } \\
\text { dan Batang } \\
\text { Pina }\end{array}$ \\
\hline 26 & Sengkubak & $\begin{array}{l}\text { Pycnarrhena } \\
\text { cauliflora }\end{array}$ & Daun & $\begin{array}{l}\text { Bumbu } \\
\text { masakan, } \\
\text { kompres } \\
\text { penurun panas } \\
\text { dan obat } \\
\text { kembung }\end{array}$ & $\begin{array}{l}\text { Penyedap } \\
\text { Rasa dan } \\
\text { obat } \\
\text { tradisional } \\
\text { (jaram dan } \\
\text { tapal) } \\
\end{array}$ \\
\hline 27 & Tampoi & $\begin{array}{l}\text { Baccaurea } \\
\text { macrocarpa }\end{array}$ & Buah & $\begin{array}{l}\text { Dapat } \\
\text { dimakan }\end{array}$ & Buah Tampoi \\
\hline 28 & $\begin{array}{l}\text { Tengkabak } \\
\text { Ramei }\end{array}$ & $\begin{array}{l}\text { Shorea } \\
\text { leprosula }\end{array}$ & Buah & $\begin{array}{l}\text { Minyak } \\
\text { Goreng }\end{array}$ & $\begin{array}{l}\text { Minyak } \\
\text { tengkawang }\end{array}$ \\
\hline 29 & $\begin{array}{l}\text { Tengkabak } \\
\text { Laye }\end{array}$ & $\begin{array}{l}\text { Shorea } \\
\text { mecistopteryx } \\
\text { Ridl. }\end{array}$ & Buah & $\begin{array}{l}\text { Minyak } \\
\text { Goreng }\end{array}$ & $\begin{array}{l}\text { Minyak } \\
\text { tengkawang }\end{array}$ \\
\hline 30 & $\begin{array}{l}\text { Uwi } \\
\text { jeronang }\end{array}$ & $\begin{array}{l}\text { Daemonorops } \\
\text { draco }\end{array}$ & Buah & $\begin{array}{l}\text { Pewarna alam, } \\
\text { dan bahan } \\
\text { kerajinan } \\
\text { tangan }\end{array}$ & $\begin{array}{l}\text { Resin } \\
\text { jeronang, } \\
\text { anyaman }\end{array}$ \\
\hline 31 & Uwi Marao & $\begin{array}{l}\text { Calamus manan } \\
\text { Mig. }\end{array}$ & Batang & $\begin{array}{l}\text { Bahan } \\
\text { membuat } \\
\text { mebel dan } \\
\text { perabot rumah } \\
\text { tangga }\end{array}$ & $\begin{array}{l}\text { Mebel dan } \\
\text { perabot } \\
\text { rumah tangga }\end{array}$ \\
\hline 32 & Uwi Sogah & $\begin{array}{l}\text { Calamus caesius } \\
\text { Blume. }\end{array}$ & Batang & $\begin{array}{l}\text { Pengikat, } \\
\text { bahan kursi, } \\
\text { takin, jarai dll }\end{array}$ & Mebel \\
\hline
\end{tabular}

ditemukan pada saat pengamatan ciri-ciri morfologisnya. Deskripsi

Hutan Sekam Galik Desa Kasro kelompok HHBK yang berhasil

Mego Kecamatan Beduai, dilakukan diidentifikasi adalah sebagai berikut :

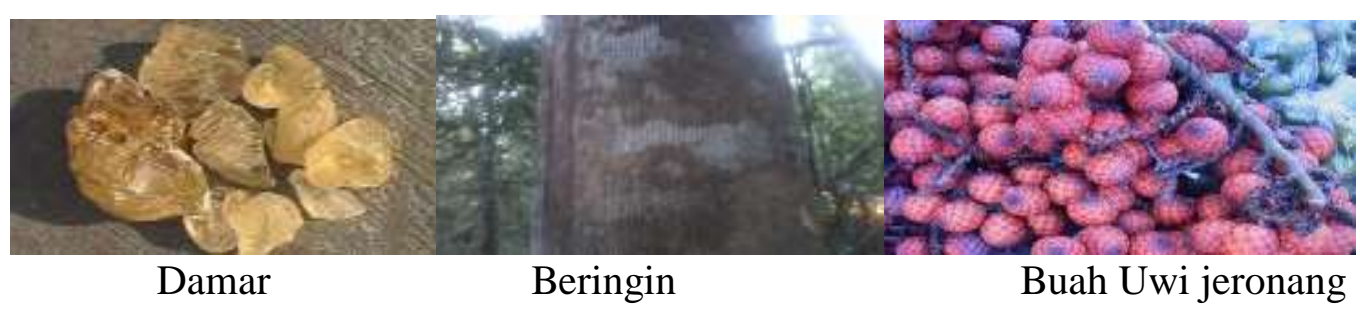


Pemanfaatan Hasil Hutan Bukan Kayu Oleh Masyarakat Galik Sekam Desa Kasro Mego Kecamatan Beduai Kabupaten Sanggau

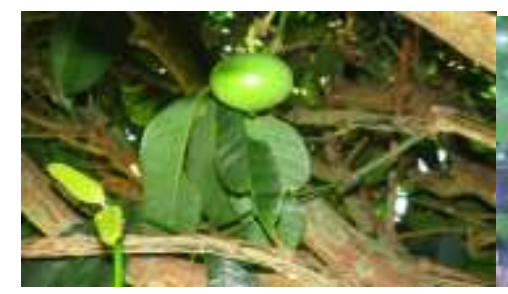

Asam Konis

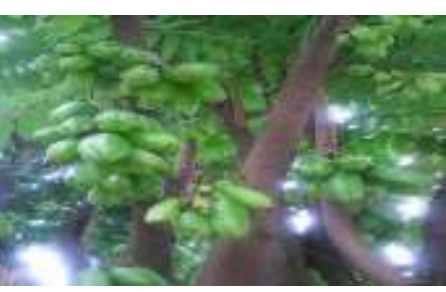

Berinang

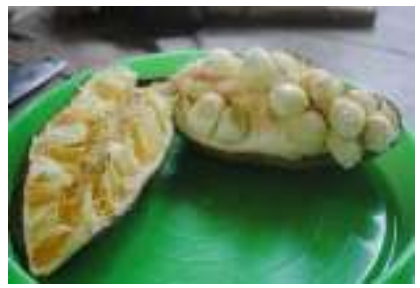

Buah Budak

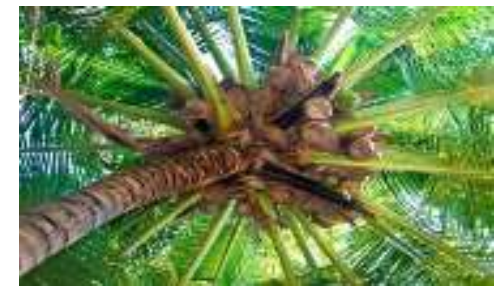

Batang Buntat

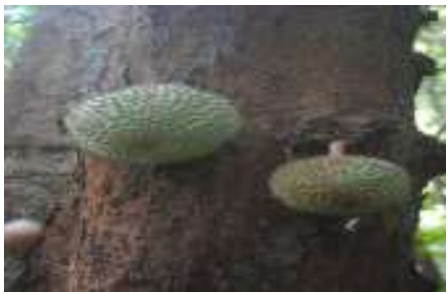

Diat

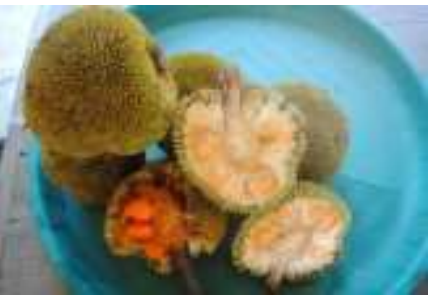

Entowok

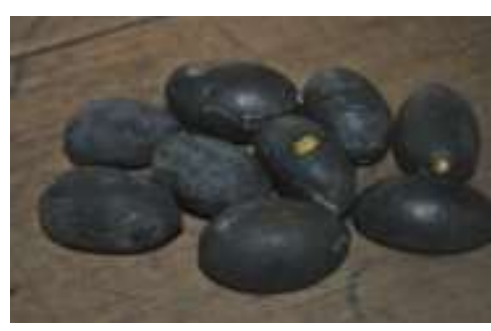

Buah Kelampai

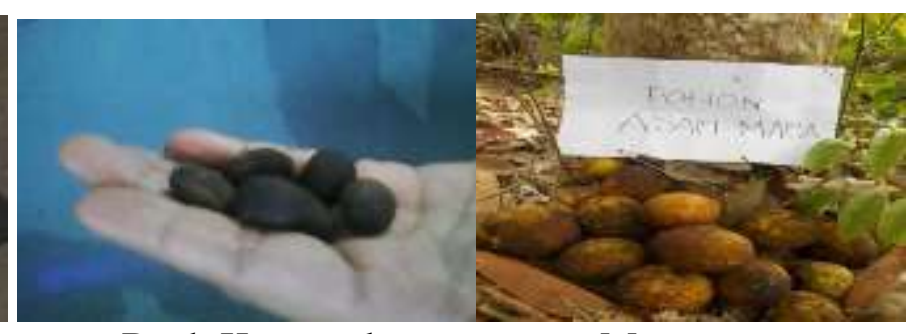

Buah Kuronyek

Maca

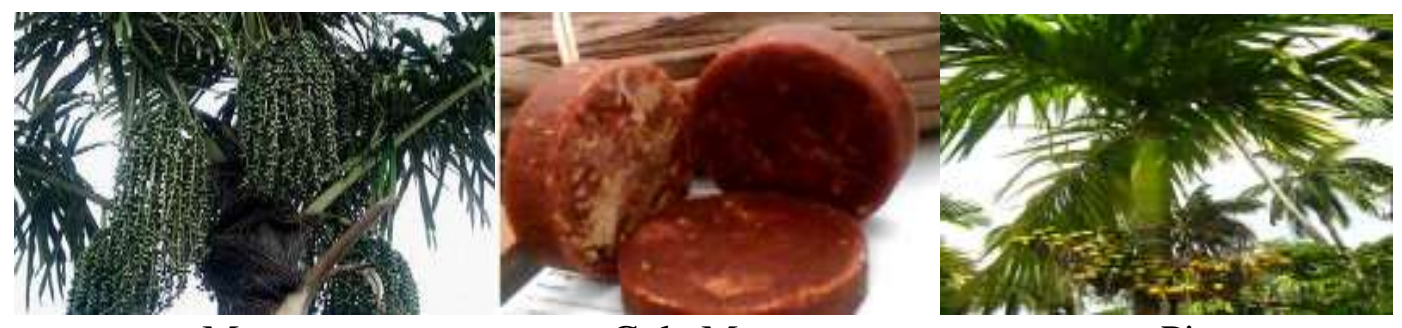

Mayang

Gula Mayang

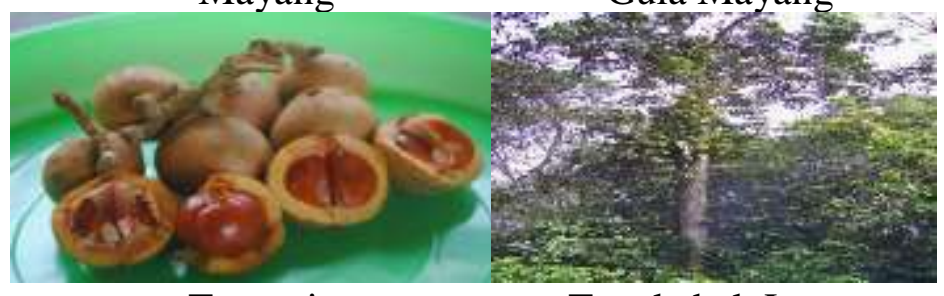

Tampoi

Tengkabak Laye

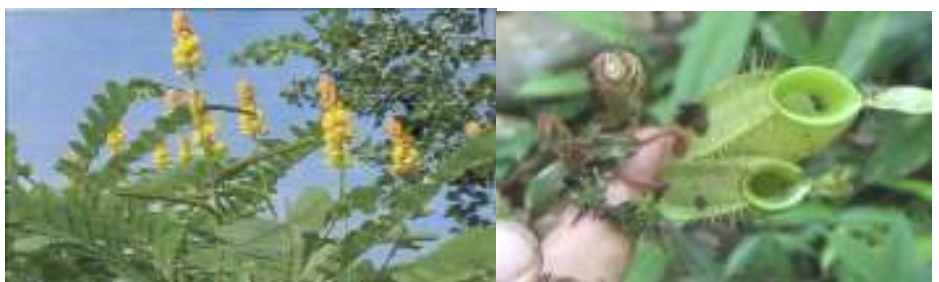

Engkudu
Kantong semar
Pina

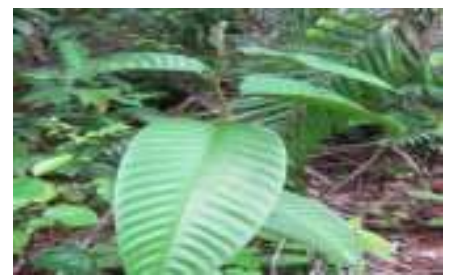

Daun Tengkabak Ramei

PIPER No.27 Volume 14 Oktober 2018

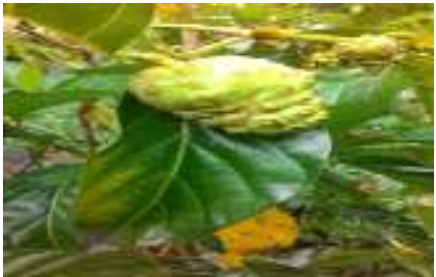

Akar Kuning 


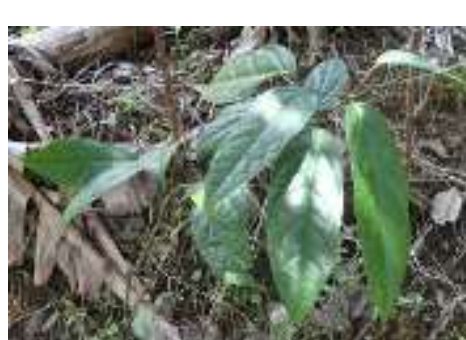

Sengkubak

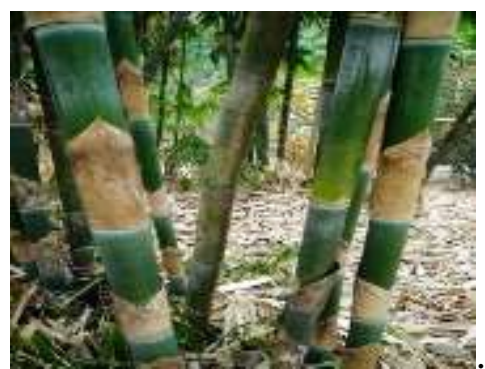

Batang Bambu

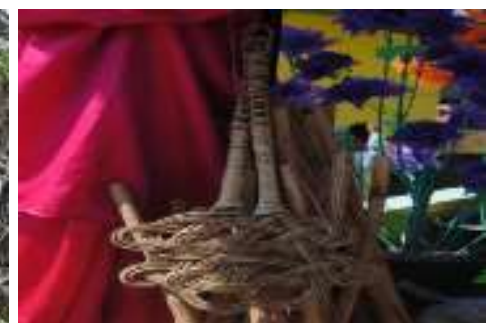

Alat Pemukul Kasur dan Bantal

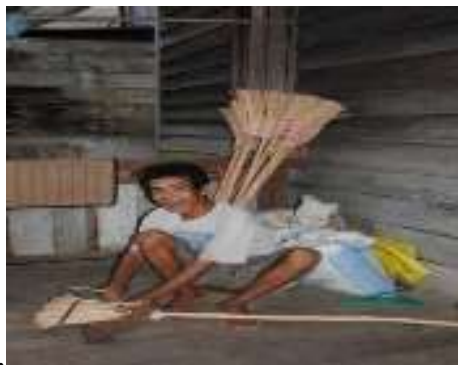

Batang Uwi Sogah

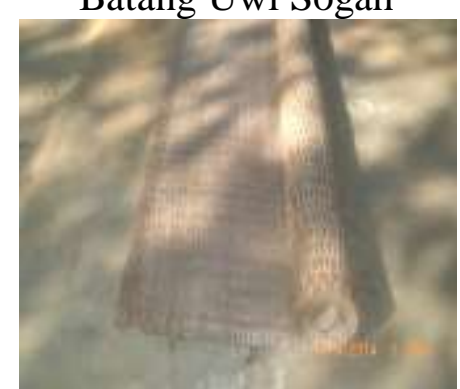

Anyaman Tikar dari Bemban

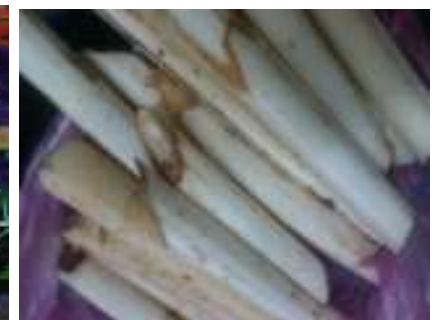

Umbut

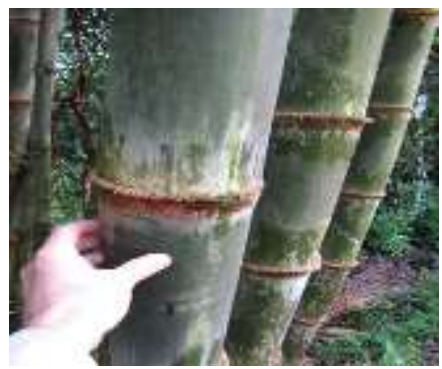

Batang Bambu Betung

Berdasarkan hasil penelitian tangan, obat-obatan dan lain ditemui bahwa di Desa Kasro Mego sebagainya. Bila dilihat dari ada sumber daya alam yang tergolong ke dalam Hasil Hutan Bukan Kayu. Akan tetapi pengelompokan ini berdasarkan Permenhut no. 35 Tahun 2007 yang mengatur sumber daya alam sebagai HHBK.

Masyarakat

setempat

mengelompokkan sumber daya alam mini berdasarkan manfaat atau kegunaan sehari-hari, seperti Permenhut no 35 tahun 2007 tersebut, maka ada beberapa jenis tumbuhan yang penggolongannya lebih dari satu kelompok. Hal ini mengingat bahwa dari dulu masyarakat lokal yang mayoritas etnis Dayak sudah terbiasa memanfaatkan sumber daya hutan untuk memenuhi kebutuhannya. Sehingga hampir semua yang ada di misalnya untuk konsumsi, kerajinan alam dapat dimanfaatkan, hanya 
yang menjadi keterbatasan adalah pengetahuan dalam mengolah dan kurangnya sumber daya manusia setempat.

Tercatat sebanyak 7 jenis tumbuhan yang digunakan sebagai bahan obat tradisional. Sedikitnya Kelompok Tumbuhan Obat yang ditemukan pada saat penelitian dapat disebabkan oleh pengetahuan obatobatan tradisional ini hanya banyak dimiliki oleh generasi tua dan mudahnya masyarakat mendapatkan pelayanan fasilitas kesehatan yang diberikan oleh pemerintah setempat. Tumbuhan obat-obatan tradisional yang dimanfaatkan oleh masyarakat dalam menyembuhkan berbagai macam penyakit, yaitu sebagai Penawar bisa ular, Obat telinga bernanah, Obat demam, Obat sakit kuning, Obat sakit malaria, Obat sakit pinggang, Obat luka koreng dan lain-lain. Obat-obatan tradisional tersebut merupakan obat dalam (diminum atau dimakan) dan obat luar (dioles atau ditempel). Bagian yang digunakan untuk bahan meramu obat-obatan tradisional tersebut adalah ; Batang, Kantong, Akar, Daun dan buah. Pemanfaatan
Kelompok Palma dan Bambu di Hutan Galik Sekam oleh masyarakat di desa Karo Mego masih banyak dilakukan sampai saat ini, karena potensi yang masih berlimpah. Pada saat penelitian ditemukan 8 jenis Kelompok Palma dan Bambu banyak dipergunakan sendiri, seperti untuk bahan pembuatan mebel, anyamanyaman, tali pengikat, perabot rumah tangga dan lain-lain. Selain itu terdapat jenis Palma dan Bambu yang dapat dikonsumsi seperti umbut, rebung, bahan pembuat gula, bahan pembuat kolang kaleng dan bahan pembuat arak atau tuak. Sedangkan bagian yang digunakan adalah ; umbut, buah, air, batang dan lidi. Selain kelompok HHBK jenis tumbuhan yang disebutkan diatas, juga terdapat kelompok lainnya yaitu jenis Bemban, Kepuak dan Pandan. Kelompok ini bermanfaat sebagai bahan berbagai kerajinan tangan dan tali pengikat. Hasil produk dari kelompok ini merupakan andalan dari masyarakat Desa Kasro Mego, karena selain untuk keperluan sendiri, juga memiliki nilai jual yang dapat dipasarkan dan sangat membantu perekonomian 
masyarakat. Bagian yang adat bagi masyarakat dalam menjaga dimanfaatkan dari Kelompok ini kelestarian hutan tersebut.

adalah ; batang, kulit dan daun.

Pemanfaatan HHBK oleh masyarakat Desa Kasro Mego mempunyai peranan penting untuk keperluan sendiri dan menambah penghasilan pendapatan masyarakat itu sendiri, namun harus ada upayaupaya untuk dapat meminimalisir dampak negatif pemanfaatan HHBK yang berlebihan terhadap ekosistem alami Hutan Galik Sekam. Mengingat semakin berkurangnya luas Hutan Galik Sekam akibat perambahan atau penebangan liar, perladangan berpindah serta kebakaran hutan yang terjadi dalam beberapa tahun terakhir, maka akan berdampak terhadap sosial ekonomi masyarakat itu pula. Langkah yang bijak sudah dilakukan oleh aparatur desa dan tokoh masyarakat setempat dengan menetapkan Hutan Galik Sekam sebagai Hutan Tutupan Adat melalui Surat Keputusan Kepala Desa Kasro Mego Nomor 9/KD/KM/2009 tanggal 20 Oktober 2009. Dalam perlindungan atau pengawasan hutan tersebut telah ditetapkan aturan-aturan atau sangsi

\section{KESIMPULAN}

Berdasarkan hasil penelitian maka dapat ditarik kesimpulan sebagai berikut:

1. Ditemukan 4 kelompok HHBK yang dimanfaatkan oleh masyarakat Desa Kasro Mego Kecamatan Beduai terdiri dari Kelompok Resin 2 jenis : Damar dan gaharu; Kelompok Minyak Lemak, Pati dan Buah-buahan sebanyak 13 jenis, yaitu ; Asam Konis, Berinang, Budak, Buntat, Diat, Engkudu, Entowok, Kelampai, Kuronyek, Maca, Mayang, Pina, Tampoi, Tengkabak Laye dan Tengkabak Ramei; Kelompok Tannin, getah dan pewarna ada 1 jeni yaitu : Uwi Jeronang; Kelompok Tumbuhan Obat sebanyak 7 buah, yaitu ; Akar Entuyut, Akar Kuning, Akar Rido, Engkudu, Ketepeng, Sengkubak dan Pina. Kelompok Palma dan Bambu sebanyak 8 jenis, yaitu ; Buntat, Uwi jeronang, Uwi Marao, Uwi Sogah, Bambu Betung, Bambu 
Munti, Bambu Tengayang dan Mayang. Kelompok lainnya 3 jenis, yaitu ; Bemban, Kepuak dan Pandan.

2. Beberapa jenis tumbuhan mempunyai manfaat lebih dari satu dalam kelompok atau kategori HHBK, seperti ; Uwi jeronang yang masuk dalam kelompok Resin dan Bahan Pewarna, Kelompok Minyak Lemak, Pati dan Buah-buahan, Kelompok Tumbuhan Obat dan Kelompok Palma dan Bambu. Tumbuhan Engkudu yang masuk dalam Kelompok Minyak Lemak, Pati dan Buah-buahan serta Kelompok Tumbuhan Obat. Tumbuhan Pina masuk dalam Kelompok Minyak Lemak, Pati dan Buah-buahan serta Kelompok Tumbuhan Obat. Tumbuhan Buntat masuk dalam Kelompok Minyak Lemak, Pati dan Buahbuahan serta Kelompok Palma dan Bambu.

3. Potensi HHBK yang masih ada di Hutan Galik Sekam dapat dilihat dari pemanfaatan oleh masyarakat yang masih ada pula. Kelompok Minyak Lemak, Pati dan Buah- buahan merupakan kelompok yang paling banyak ditemukan dan dimanfaatkan oleh masyarakat Desa Kasro mego. Walaupun terdapat pula kelompok jenis-jenis yang mulai berkurang atau susah ditemukan, seperti pada Kelompok Resin dan Bahan Pewarna (gaharu dan uwi jeronang) dan Kelompok Hewan dan Hasil Hewan (Laba, Muncak, Peronuk dan Lebah).

4. Pemanfaatan HHBK oleh masyarakat Desa Kasro Mego mempunyai peranan penting untuk keperluan sendiri dan menambah penghasilan pendapatan masyarakat itu sendiri.

Perlunya pengakuan atau penetapan oleh instansi terkait terhadap Hutan Galik Sekam Desa Kasro Mego Kecamatan Beduai Kabupaten Sanggau sebagai Hutan Tutupan Adat sesuai peraturan yang berlaku. Pengetahuan dan kesadaran masyarakat terhadap manfaat HHBK dalam kehidupan sehari-hari perlu dilakukan pembinaan lebih lanjut guna menjaga kelestarian HHBK itu sendiri. 
Pemanfaatan Hasil Hutan Bukan Kayu Oleh Masyarakat Galik Sekam Desa Kasro Mego Kecamatan Beduai Kabupaten Sanggau

\section{DAFTAR PUSTAKA}

Alkadri,dkk. (ed).2001. Tiga Pilar dalam Pengembangan Wilayah : Sumberdaya Alam, Sumberdaya Manusia. Teknolog. Jakarta : BPPT.

Arnold, J.E.M. dan M.R. Perez. 1998. The role of non-timber forest products in conservation and development income from forest. CIFOR-IUCN. Bogor.

Departemen Kehutanan, 2007, Peraturan Pemerintah Nomor. 6 Tahun 2007 tanggal 8 Januari 2007 tentang Tata Hutan dan Rencana Pengelolaan Hutan serta Pemanfaatan Hutan, Jakarta.

Ehrenfeld, D. W. 1988. Why Put a Value on Biodiversity? In Biodiversity (E. O. Wilson and F. M. Peter, eds.), National Academi Press Washington, D.C., pp. 212-216.

Marit, H. 2008. Manajemen Hutan Indonesia.

http://hasrulmarit.blogspot.com.

Diunduh tanggal 21 Februari 2014.

Peraturan Republik Indonesia 1999, Undang-undang No. 41 tahun

\section{9 tentang Kehutanan Jakarta.}

Primack, R. B. 1993. Essentials of Conservation Biology. Sinauer Associates Inc. Massachusetts USA.

Sardjono. 2004. Mosaik Sosiologis Kehutanan : Masyarakat Lokal, Politik dan Kelestarian Sumberdaya, Penerbit Debut Wahana Sinergi, Jakarta.

Soetrisno, 1995. Problematika Sosial Masyarakat Sekitar kawasan Hutan di Indonesia dan Etika Pemanfaatan Sumberdaya Hutan. Fahutan UGM, Yogyakarta.

Sugiyono 2012. Memahami Penelitian Kualitatif. Alfabeta, Bandung

Suharisno, 2009. Grand Strategy Pengembangan Hasil Hutan Bukan Kayu Nasional. Prosiding Workshop Pengembangan Hasil Hutan Bukan Kayu Pada: Pekan Raya Hutan dan Masyarakat 2009 Universitas Gadjah Mada, di Yogyakarta. Yogyakarta, p. 128. 